DOI: https://doi.org/10.17308/geology.2020.4/3133

Поступила в редакцию: 25.11.2020

Принята к публикации: 01.12 .2020

Опубликована онлайн: 18.12 .2020
ISSN 1609-0691

Received: 25.11 .2020

Accepted: 01.12.2019

Published online: 18.12.2020

\title{
Памяти Митрофана Степановича Точилина
}

\author{
А. М. Плякин ${ }^{\bowtie}$ \\ Ухтинский государственный технический университет, \\ ул. Первомайская, 13, 169300, Ухта, Республика Коми, Российская Федерация
}

\section{Memory of Mitrofan S. Tochilin}

\author{
A. M. Plyakin ${ }^{\bowtie}$ \\ Ukhta State Technical University, 13 Pervomayskaya st., \\ 169300, Ukhta, Republic of Komi, Russian Federation
}

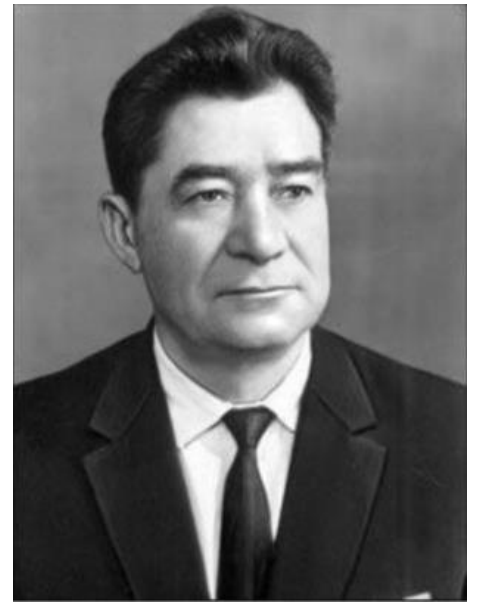

15 декабря 2020 года исполняется 110 лет со дня рождения одного из выдающихся учёных-геологов нашего университета, нашей страны - Митрофана Степановича Точилина. Больше полувека его нет с нами, но благодарная память о нём сохраняется в наших сердцах, сердцах его учеников.

Он окончил геологический факультет Пермского университета, а в Воронежском (ВГУ) начал работать ассистентом с 1939 г. вместе с выпускником ВГУ, будущим академиком, министром геологии СССР Александром Васильевичем Сидоренко.

Мне повезло учиться на геологическом факультете
ВГУ в те годы, когда Митрофан Степанович заведовал кафедрой минералогии и петрографии и читал нашему курсу в 1954-1955 гг. лекции по минералогии и кристаллографии. Помню, как он проводил для нас, студентов 2-го курса, консультации в небольшом кабинете старого корпуса университета, располагавшегося в те годы на Проспекте Революции. Он был очень внимателен, никогда не повышал голос, а если ему приходилось делать нам замечания, то делал это очень спокойным ровным голосом. На все вопросы по минералам и кристаллам минералов мы всегда получали очень полные и ясные ответы.

После получения диплома я был направлен в Коми АССР, в Ухтинскую геологоразведочную экспедицию на поиски и разведку редкометалльно-редкоземельных месторождений. Проработав на этих и тематических работах по докембрию Тимана 5 лет, я планировал заняться геологической съёмкой, но из-за болезни сына, по рекомендации врачей пришлось вернуться с семьёй в Воронеж. Меня принял на свою кафедру Николай Павлович Хожаинов.

Ещё в Ухте я стал кандидатом в члены Коммунистической партии, и когда подошёл срок становиться членом КПСС, уже в Воронеже, меня на заседании парткома Воронежского университета представлял Митрофан Степанович. Помню, после его вступительного слова один из членов парткома спросил, почему я до сих пор не поступил в аспирантуру. Митрофан

Контент доступен под лицензией Creative Commons Attribution 4.0 License.

The content is available under Creative Commons Attribution 4.0 License.

凹 Плякин Анатолий Митрофанович, e-mail: aplyakin09@yandex.ru 
Степанович сказал, что не прошло ещё и полугода моей работы на кафедре Общей геологии, поэтому об этом говорить рано, хотя в планах кафедры моё поступление в аспирантуру под руководством Николая Павловича Хожаинова планируется. Он поздравил меня с вступлением в КПСС и пожелал учесть пожелание парткома и поступить в аспирантуру.

Митрофан Степанович провел очень большую учебную и научно-исследовательскую работу. Он внёс огромный вклад в изучение железорудных месторождений Липецка, Курской Магнитной Аномалии, Кольского полуострова. На основании этих исследований он впервые пришёл к установлению генетической связи образования железистых кварцитов с подводным вулканизмом. Это направление науки стало темой его докторской диссертации «Происхождение, распространение и поисковые признаки Липецких железных руд».

По просьбе своего бывшего коллеги и друга Александра Васильевича Сидоренко Митрофан Степанович несколько лет руководил Лабораторией региональной геологии Геологического института Кольского филиала АН СССР. По его представлению выпускник ГФ ВГУ Владимир Евзеров, мой однокурсник-одногруппник и друг, стал аспирантом Александра Васильевича и успешно защитил канди- датскую, а в последующем - докторскую диссертации.

За свою короткую, 58-летнюю жизнь Митрофан Степанович добровольцем принял участие в Великой Отечественной войне, провёл успешную научную и преподавательскую работу, к которой привлек множество выпускников геологического факультета ВГУ. Многие из них в усвоенном от него стиле успешно продолжали научные геологические исследования и подготовку профессионалов-геологов высокого класса.

Боевые заслуги Митрофана Степановича оценены орденами «Отечественной войны» I ст. и «Красной звезды», медалями «За отвагу», «За оборону Москвы»», «За взятие Будапешта», «За взятие Вены» и «За Победу в Великой Отечественной войне 1941-1945 гг.». Его успешная научная и преподавательская деятельность отмечена орденом «Трудового Красного Знамени» и медалью «За трудовую доблесть».

Имя Митрофана Степановича Точилина присвоено открытому его учеником Сергеем Молотковым минералу - «точилинит»».

Многие его ученики бережно хранят добрую, благодарную память о замечательном, добром и отзывчивом человеке, внимательном учителе, выдающимся учёном - Митрофане Степановиче Точилине.

К этим его ученикам отношу себя и я.
Для цитирования: Плякин А. М. Памяти Митрофана Степановича Точилина // Вестник Воронежского государственного университета. Серия: Геология. 2020. №4. C. 97-98.

DOI: https://doi.org/10.17308/geology.2020.4/3133

Конфликт интересов: Авторы декларируют отсутствие явных и потенциальных конфликтов интересов, связанных с публикацией настоящей статьи.
For citation: Plyakin A. M. In memory of Mitrofan S. Tochilin. Vestnik Voronezhskogo gosudarstvennogo universiteta. Seriya: Geologiya $=$ Proceedings of Voronezh State University. Series: Geology, 2020, no. 4, pp. 97-98.

DOI: https://doi.org/10.17308/geology.2020.4/3133

Conflict of interests: The authors declare the absence of obvious and potential conflicts of interest related to the publication of this article.
Плякин Анатолий Митрофанович - к.г.-м.н., профессор, Ухтинский государственный технический университет, Ухта, Республика Коми, Российская Федерация;

E-mail: aplyakin09@yandex.ru

Автор прочитал и одобрил окончательный вариант рукописи.
Anatoliy M. Plyakin - PhD in Geol-Min., professor, Ukhta State Technical University, Ukhta, Republic of Komi, Russian Federation; E-mail: aplyakin09@yandex.ru

Author have read and approved the final manuscript. 